\title{
JLミCOV
}

\section{Energy consumption, economic development and environmental degradation nexus for Nigeria}

\author{
David Ashibi Ushie ${ }^{1}$ \\ Esther Ranmilowo Aderinto ${ }^{2}$ \\ 1 Lead City University, Economics Department, Ibadan, Oyo State, Nigeria, e-mail: davidashibi@yahoo.com \\ 2 Lead City University, Economics Department, Ibadan, Oyo State, Nigeria, e-mail: esthercareer@yahoo.com
}

\begin{abstract}
This study tests the existence of the Environmental Kuznets Curve (EKC) hypothesis for Nigeria using two environmental indicators vis-à-vis ecological footprint and carbon dioxide emissions. Data was sourced from World Development Indicators (WDI) and the Global Footprint Network for the period spanning from 1981 to 2019.The Auto Regressive Distributed Lag (ARDL) method was employed. It was observed that short-run and long-run relationships exist among the variables. Findings revealed that in the short and long run, energy consumption has positive effects on $\mathrm{CO} 2$ emissions in Nigeria. However, for ecological footprint, only energy consumption in the three lagged period has a positive relationship with EFP in the short run without any significant effect being observed in the long run. Similarly, an inverted U-shaped environmental degradation-economic development relationship was established in the study which validated the EKC hypothesized inverted U-shape for CO2 emissions. However, for EFP, there was no evidence of the EKC. As such, the shape of the EKC curve is subject to the environmental indicators employed. The study therefore recommends an increase in the use of alternative sources of energy that are relatively free from pollutant emissions as an alternative and viable option for Nigeria.
\end{abstract}

Keywords: Energy consumption, economic development, environmental degradation, GDP per capita, EKC hypothesis. JEL codes: $\mathrm{O} 13$ 


\section{INTRODUCTION}

Global energy consumption is dominated with the fossil fuels otherwise known as non-renewable energy constituting about 84 percent, while renewable energy accounts for 16 percent. The global mix of non- renewable energy is disaggregated into 36 percent for crude oil, 26 percent for coal and 22 percent for natural gas while the renewable mix is made up of hydro accounting for 7 percent, nuclear for 5 percent and other renewables such as wind, solar, biofuels accounting for 4 percent (Energy Information Administration, 2019). Energy consumption remains the main source of human-induced greenhouse gas emissions, contributing about $76 \%$ of emissions worldwide (World Resources Institute, 2021). Global emissions are largely attributed to the top sectors of the economy, like, agriculture, industry and energy.

The demand for energy is growing faster than its supply; thus, stirring the need for government of different countries to boost energy supplies in response to the growing demand. As posited by Odularo and Okonkwo (2009), this is because energy is the driving force for economic growth and improved living standard. Most production and consumption activities revolve around energy as an essential input. Global economies rely heavily on energy and Nigeria is not an exception. Nigeria is regarded as the giant of Africa and has a huge endowment of energy resources.

The energy situation in Nigeria is dominated by the fossil fuels as total primary energy consumption stood at 1.1 Quadrillion Btu in 2005, while in 2018, primary energy consumption for Nigeria was 1.66 quadrillion Btu. For Nigeria, the rapidly growing energy demand is met dominantly through the fossil fuels especially crude oil and natural gas. This huge dependence on fossil fuel consumption has contributed significantly to environmental degradation in Nigeria. Emissions from energy consumption in Nigeria has been on the increase, rising steadily from 22730 thousand metric tons (mt) in 2001, to 24005 thousand metric tons in 2011 and substantially to 104.27 thousand metric tons in 2018. Similarly, with a population of over 200 million people, there has been a substantial increase in energy consumption in Nigeria over the years.

Given that the Nigerian economy is the largest economy in Africa, there is no gainsaying that this development has its impact on environmental quality. The Nigerian economy is dominated by pollution-intensive sectors (agriculture, oil and gas, manufacturing). About 65 percent of the country's population is engaged in the agricultural sector and the sector contributes about 24 percent to Gross Domestic Product and $76.19 \mathrm{mt}$ of greenhouse gas emissions (Nigerian Bureau of Statistics, 2020; World Resources Institute, 2021). Despite the dominance of this sector, the petroleum sub-sector accounts for about $80 \%$ of government revenues, $90-95 \%$ of export revenues, and over $90 \%$ of foreign exchange earnings in Nigeria. This sector contributes about $197.18 \mathrm{mt}$ of greenhouse gas emissions. The contribution of the manufacturing sector to Gross Domestic Product (GDP) was about 28 percent in 2020, with a contribution of about $23.98 \mathrm{mt}$ to greenhouse gas emissions (NBS, 2020; World Resources Institute, 2021). All these country-specific factors have significant implications on environmental degradation for Nigeria.

Literature abounds on the energy-environment nexus across countries with the most common measurement for environmental degradation being carbon dioxide emissions. However, in recent times, the Ecological Foot print (EFP) has been introduced as a measure of environmental degradation. Alola et al. (2019) submits that EFP emphasizes human demand on biological resources by highlighting the components of impact in terms of land (or sea) area.

Since the 1970s, there has been a steady increase in the consumption of natural resources across the world as global consumption of natural resources has increased by 50 percent. However, this does not match up with the available resources as this has been recorded to have decreased by over 30 percent since then. A global average EFP of 2.75 global hectares per person was recorded in 2016 with a corresponding global average biocapacity of 1.63 global hectares per person (Global footprint, 2018).

Given the threats of climate change and the need to mitigate against it, it is important to evaluate the effect of energy consumption on environmental degradation in Nigeria for appropriate environmental policies. This study, therefore seeks to contribute to existing literature by employing two environmental degradation indicators vis-à-vis the ecological footprint and $\mathrm{CO} 2$ emissions.

In the light of energy-environment discussions for $\mathrm{Ni}$ geria, most studies have employed $\mathrm{CO} 2$ emissions in estimating environmental degradation (Aiyetan and Olomola, 2009; Nathaniel, 2020, Omisakin, 2009; Akpan and Chuku, 2011). However, this study examines the effect of energy consumption on environmental degradation in Nigeria by employing two measures of environmental degradation vis-à-vis $\mathrm{CO} 2$ emissions and EFP. This study also tests the validity of the EKC hypothesis for Nigeria using the two indicators to ascertain whether or not the influence of economic development on the environment depends on the indicator employed.

For the energy-environment relationship, the first strand of literature focused mainly on the energy consumption-economic growth relationship. In the 
light of this, four hypotheses have been established. The conservative hypothesis established a unidirectional relationship from economic growth to energy consumption, while supporting energy conservation policies with modest or no undesirable effect on economic growth. Conversely, the growth hypothesis emphasized a unidirectional relationship from energy consumption to economic growth. This implies an energy-dependent economy in which energy conservation policies could impede economic growth (Adeniran, 2009; Tsani, 2010; Odhiambo, 2010). The feedback hypothesis posited a complementary association between energy consumption and economic growth (Omotor, 2008). Finally, the neutral hypothesis refers to a situation in which there is no association between energy consumption and economic growth (Ezatollah et al, 2010; George and Nickolas, 2011).

Another line of literature has focused on the dynamic relationships between energy consumption, economic growth and environmental degradation. Most studies in this regard have analysed the relationship within the context of the Environmental Kuznets Curve (EKC) hypothesis, which posits an inverse U-shape relationship between economic development and environmental pollution. The theory explains that environmental degradation increases with economic development, until a point is reached at which environmental degradation starts to decline with further increase in economic development.

Empirical evidence on the existence of the EKC in Nigeria is at best mixed (Egbetokun et al., 2019; Aiyetan and Olomola, 2017; Alege and Ogundipe, 2013; Akpan and Chuku, 2011). While some studies have confirmed the existence (Egbetokun et al., 2019; Aiyetan and Olomola, 2017; Ali et al., 2021), others have refuted the evidence (Chuku,2011; Alege and Ogundipe, 2013). Differences in the result could be attributed to the different estimation techniques employed by different researchers as well as variables employed in the study. There is also paucity of literature on Ecological Footprint as a measure of environmental degradation for Nigeria. This study seeks to investigate if the effect of per capita GDP on environmental degradation for Nigeria is subject to the environmental indicator employed (CO2 emissions or EFP), hence the justification for this study.

\section{METHODOLOGY}

The study adopts the EKC hypothesis which explains the relationship between economic development and environmental degradation. The theory suggests that as income increases, emissions would also increase until a level of income is reached at which emissions start to decline. This turning point is the point at which development further advances, following an increase in economic activity, technological improvement and information diffusion which reduces environmental degradation. The study employs yearly data from 1981 to 2019 for Nigeria. The variables of interest for the study are energy consumption (E), gross domestic product (GDP) per capita, the square value of gross domestic product per capita (GDP2), ecological footprint (EFP), $\mathrm{CO} 2$ emissions (CO2) and gross fixed capital formation (GFCF). Data for all variables except EFP were obtained from World Development Indicators, while EFP data was sourced from Global Footprint Network.

For the EKC hypothesis, if $\beta 1=\beta 2=0$, there is no relationship between per capita income and environmental degradation, if $\beta 1>0$, and $\beta 2=0$, a linear increasing relationship exists, if $\beta 1<0, \beta 2=0$, a monotonic decreasing relationship exists, if $\beta 1>0, \beta 2<0$, an inverted $U$ relationship that validates the EKC exists, if $\beta 1<0, \beta 2$ $>0$, a U-shaped relationship exists.

Following the standard EKC specification, the model specification is given as:

$$
\begin{aligned}
& \ln C O_{2 t}=\beta_{0}+\beta_{1} \ln G D P_{t}+\beta_{2} \ln G D P_{t}^{2}+\beta_{3} \ln E_{t}+\beta_{4} \ln G F C F_{t}+\mu_{t} \\
& \ln E F P_{t}=\beta_{0}+\beta_{1} \ln G D P_{t}+\beta_{2} \ln G D P_{t}^{2}+\beta_{3} \ln E_{t}+\beta_{4} \ln G F C F_{t}+\mu_{t}
\end{aligned}
$$


Two models are analysed following the use of two environmental indicators (EFP and CO2). Where $\beta 1$ to $\beta 4$ are the coefficients of the variables, $\ln \mathrm{CO} 2$ is $\log$ of carbon dioxide emissions, lnEFP is the log of ecological footprint, lnGDP is log of Gross Domestic Product per capita, $\ln (\mathrm{GDP}) 2$ is $\log$ of the square value of Gross Domestic Product per capita, $\ln E$ is log of Energy Consumption, lnGFCF is log of Gross Fixed Capital Formation and $\mu \mathrm{t}$ is the error term.

In analyzing the relationship, an Autoregressive Distributed Lag (ARDL) model framework is employed. The ARDL approach estimates both the long-run and short-run parameters irrespective of whether the variables are integrated of order I(1) or I(0), (Pesaran and Shin, 1995) and also works well with small samples. A prerequisite for the ARDL estimation is the Bounds Test of cointegration used in investigating the longrun relationship between the variables of interest at $5 \%$ level of significance.

Two ARDL models are estimated using the two indicators (CO2 emissions and EFP). Following Saboori and Sulaiman (2013) as well as Mrabet and AlSamara (2016) with some modifications, the ARDL model specification is given as:

$$
\begin{aligned}
\Delta l n C O_{2 t}=\beta_{0}+ & \sum_{i=1}^{n} \beta_{1} \Delta \ln C O_{2 t-1}+\sum_{i=1}^{n} \beta_{2} \Delta \operatorname{lnGDP_{t-1}}+\sum_{i=1}^{n} \beta_{3} \Delta \operatorname{lnGDP_{t-1}^{2}}+\sum_{i=1}^{n} \beta_{4} \Delta \ln E_{t-1} \\
& +\sum_{i=1}^{n} \beta_{5} \Delta \ln G F C F_{t-1}+\alpha_{1} \operatorname{lnCO} 2 t-1+\alpha_{2} \ln G D P_{t-1}+\alpha_{3} \ln G D P_{t-1}^{2}+\alpha_{4} \ln E_{t-1} \\
& +\alpha_{5} \ln G F C F_{t-1}+\mu_{t}
\end{aligned}
$$$$
\Delta \operatorname{lnEFP_{t}}=\beta_{0}+\sum_{i=1}^{n} \beta_{1} \Delta \operatorname{lnEFP_{t-1}}+\sum_{i=1}^{n} \beta_{2} \Delta \operatorname{lnGDP_{t-1}}+\sum_{i=1}^{n} \beta_{3} \Delta \operatorname{lnGDP_{t-1}^{2}}+\sum_{i=1}^{n} \beta_{4} \Delta \ln E_{t-1}
$$

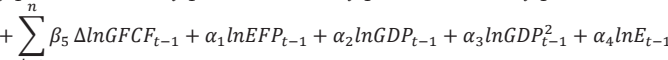$$
+\alpha_{5} \operatorname{lnGFCF} F_{t-1}+\mu_{t}
$$

\section{RESULTS AND DISCUSSIONS}

\subsection{Descriptive Statistics}

This is used to summarize the basic features of the data. The mean and the median are both measures of central tendency; they give an indication of the average value of a distribution of figures. Similarly, the standard deviation evaluates the deviation of each data set from the mean of the distribution.

The mean of the data set is calculated based on the formula:

$$
\operatorname{Mean}\left(\overline{X)}=\sum \frac{X}{N}\right.
$$

While the median is given as:

$$
\begin{gathered}
\text { Median }=\left(\frac{n+1}{2}\right) \text { th observation } \\
\text { Standard deviation }=\sqrt{\sum \frac{x_{i-} \mu^{2}}{N}}
\end{gathered}
$$

The results of the descriptive statistics are presented in Table 3.1. below.

From the table presented above, the Jarque-Bera statistics suggest the normality of the residual.

\subsection{Correlation Matrix}

The correlation matrix is a pre-estimation test that examines the positive and negative correlations for variables while revealing the presence (absence) of multicollinearity in the estimated models.

Where $\beta 1$ to $\beta 4$ are the short run coefficients and $\alpha 1$ to $\alpha 4$ are the long run coefficients of the variables.

Table 1: Descriptive Statistics

\begin{tabular}{|l|l|l|l|l|l|}
\hline & $\mathrm{CO}_{2}$ & EFP & ENERGY & GCF & GDP \\
\hline Mean & 0.368 & 1.152 & 722.540 & $3.34 \mathrm{E}+10$ & 10.268 \\
\hline Median & 0.311 & 1.169 & 718.152 & $1.93 \mathrm{E}+10$ & 10.045 \\
\hline Maximum & 0.645 & 1.383 & 798.630 & $7.46 \mathrm{E}+10$ & 11.153 \\
\hline Minimum & 0.226 & 0.970 & 671.906 & $9.57 \mathrm{E}+09$ & 9.531 \\
\hline Std Deviation & 0.127 & 0.099 & 37.419 & $2.23 \mathrm{E}+10$ & 0.561 \\
\hline Skewness & 0.790 & 0.274 & 0.297 & 0.750 & 0.344 \\
\hline Kurtosis & 2.341 & 2.707 & 1.702 & 1.911 & 1.630 \\
\hline Jarque-Bera & 4.645 & 0.613 & 3.228 & 5.439 & 3.722 \\
\hline Probability & 0.098 & 0.736 & 0.199 & 0.065 & 0.155 \\
\hline Sum & 13.988 & 43.781 & 27456.53 & $1.27 \mathrm{E}+12$ & 390.219 \\
\hline
\end{tabular}

Source: Author's Computation using Eviews 11 (2021) 
The correlation table shown above shows positive and negative correlations for variables while revealing the absence of multicollinearity in the two estimated models.

\subsection{Unit Root Test}

The test for stationarity is pivotal in ensuring that the variables are estimated in their stationary forms to avoid spurious result. To do this, both the Augmented Dickey-Fuller (ADF) and Philip Perron (PP) unit root tests are used.
Results show that all variables except gross fixed capital formation are integrated of order 1(1). This justifies our choice of ARDL methodology as variables exhibit a mix of integration order $1(0)$ and $1(1)$.

\subsection{Bound test for linear co-integration}

For the ARDL bound test, the computed F-test statistics should be greater than the 0.05 lower and upper bound.

Table 2: Correlation matrix for model I

\begin{tabular}{|l|l|l|l|l|}
\hline & $\mathrm{CO}_{2}$ & ENERGY & GFC & GDP \\
\hline $\mathrm{CO}_{2}$ & 1 & -0.364 & -0.316 & -0.514 \\
\hline ENERGY & -0.364 & 1 & 0.637 & 0.530 \\
\hline GFC & -0.316 & 0.637 & 1 & 0.588 \\
\hline GDP & -0.514 & 0.530 & 0.588 & 1 \\
\hline
\end{tabular}

Source: Author's Computation using Eviews 11 (2021)

Table 3: Correlation matrix for model II

\begin{tabular}{|l|l|l|l|l|}
\hline & EFP & ENERGY & GFC & GDP \\
\hline EFP & 1 & 0.572 & 0.393 & 0.535 \\
\hline ENERGY & -0.572 & 1 & 0.637 & 0.530 \\
\hline GFC & 0.393 & 0.637 & 1 & 0.588 \\
\hline GDP & 0.535 & 0.530 & 0.588 & 1 \\
\hline
\end{tabular}

Source: Author's Computation using Eviews 11 (2021).

Table 4: ADF and PP Unit root test result.

\begin{tabular}{|c|c|c|c|c|c|}
\hline Variable & $\begin{array}{c}\text { ADF Test } \\
\text { Statistic at level } \\
\left(\mathrm{I}_{0}\right)\end{array}$ & $\begin{array}{c}\text { ADF Test } \\
\text { Statistic at } \\
\text { first difference } \\
\left(\mathrm{I}_{1}\right)\end{array}$ & $\begin{array}{c}\text { PP Test at } \\
\text { level } \\
\left(\mathrm{I}_{0}\right)\end{array}$ & $\begin{array}{l}\text { PP Test at } \\
\text { first } \\
\text { difference } \\
\left(\mathrm{I}_{1}\right)\end{array}$ & $\begin{array}{c}\text { Decision } \\
\text { value }\end{array}$ \\
\hline ENERGY & -1.185 & -5.797 & -0.922 & -6.839 & $\mathrm{I}(1)$ \\
\hline GDP & -0.096 & -3.431 & -0.561 & -3.312 & $\mathrm{I}(1)$ \\
\hline $\mathrm{GDP}^{2}$ & -0.137 & -3.494 & -0.491 & -3.372 & $\mathrm{I}(1)$ \\
\hline EFP & -1.444 & -6.154 & -1.457 & -6.154 & $\mathrm{I}(1)$ \\
\hline $\mathrm{CO}^{2}$ & -1.816 & -6.058 & -1.842 & -6.058 & $\mathrm{I}(1)$ \\
\hline GFCF & -3.902 & -------- & -3.642 & ------- & $\mathrm{I}(0)$ \\
\hline $\begin{array}{l}\text { CRITICAL } \\
\text { VALUES }\end{array}$ & & & & & \\
\hline $1 \%$ & -3.621 & -3.627 & -3.621 & -3.627 & \\
\hline $5 \%$ & -2.943 & -2.946 & -2.943 & -2.946 & \\
\hline $10 \%$ & -2.609 & -2.611 & -2.610 & -2.611 & \\
\hline
\end{tabular}

Source: Author's Computation using Eviews 11 (2021) 
Table 5: Bounds Test Result for Model I (CO2)

\begin{tabular}{|l|c|c|c|}
\hline F-Statistic & $5.77 * *$ & & \\
\hline Critical Values & $1 \%$ & $5 \%$ & $10 \%$ \\
\hline Lower Bound & 4.42 & 3.47 & 3.03 \\
\hline Upper Bound & 5.72 & 4.57 & 4.06 \\
\hline
\end{tabular}

Source: Author's Computation using Eviews 11 (2021)

Note: ${ }^{* *}$ indicates significance and rejection of the null hypothesis of no co-integration at 5\% significance level.

Table 6: Bounds Test Result for Model II(EFP)

\begin{tabular}{|l|c|c|c|}
\hline F-Statistic & $6.25^{* *}$ & & \\
\hline Critical Values & $1 \%$ & $5 \%$ & $10 \%$ \\
\hline Lower Boun & 3.29 & 2.56 & 2.23 \\
\hline Upper Bound & 4.37 & 3.49 & 3.09 \\
\hline
\end{tabular}

Source: Author's Computation using Eviews 11 (2021)

Note: ${ }^{* *}$ indicates significance and rejection of the null hypothesis of no co-integration at $5 \%$ significance level.

Bounds test for the first model indicates that the estimated F-statistic (5.77) exceeds the upper and lower bound which establishes a long-run relationship among the variables.
Bounds test for cointegration for the second model also shows that the estimated F-statistic (6.25) is greater than the lower and upper critical bound establishing that variables are cointegrated.

Table 7: ARDL results for model

\begin{tabular}{|c|c|c|c|c|}
\hline \multicolumn{5}{|c|}{$\begin{array}{l}\text { Dependent Variable: } \mathrm{LNCO}_{2} \text { Emissions } \\
\text { Selected Model: } 1,3,1,4,4 \text {. }\end{array}$} \\
\hline Variable & Coefficient & Standard Error & T-Statistics & Probability \\
\hline \multicolumn{5}{|c|}{ LONG RUN ESTIMATES } \\
\hline LNENERGY & 16.535 & 8.008 & 2.065 & $0.056^{*}$ \\
\hline LNGFC & 1.436 & 1.064 & 1.349 & 0.197 \\
\hline LNGDP & 135.620 & 49.075 & 2.763 & $0.014 * *$ \\
\hline LNGDP $^{2}$ & -333.792 & 120.335 & -2.757 & $0.014 * *$ \\
\hline \multicolumn{5}{|c|}{ SHORT RUN ESTIMATES } \\
\hline DLNENERGY & 4.367 & 1.338 & 3.263 & $0.005 * * *$ \\
\hline $\begin{array}{l}\text { DLNENERGY(- } \\
\text { 1) }\end{array}$ & -2.221 & 1.536 & -1.446 & 0.169 \\
\hline $\begin{array}{l}\text { DLNENERGY(- } \\
\text { 2) }\end{array}$ & -5.723 & 1.501 & -3.811 & $0.002 * * *$ \\
\hline DLNGFCF & 0.377 & 0.161 & 2.337 & $0.033 * *$ \\
\hline DLNGDP & 109.986 & 38.824 & 2.833 & $0.013 * *$ \\
\hline DLNGDP(-1) & -20.958 & 42.629 & -0.492 & 0.630 \\
\hline DLNGDP(-2) & 38.974 & 39.231 & 0.993 & 0.336 \\
\hline DLNGDP(-3) & 78.499 & 45.057 & 1.742 & 0.102 \\
\hline DLNGDP $^{2}$ & -240.788 & 84.934 & -2.835 & $0.012 * *$ \\
\hline DLNGDP $^{2}(-1)$ & 51.277 & 92.345 & 0.555 & 0.587 \\
\hline DLNGDP $^{2}(-2)$ & -79.595 & 84.675 & -0.940 & 0.362 \\
\hline $\operatorname{DLNGDP}^{2}(-3)$ & -161.238 & 96.180 & -1.676 & 0.114 \\
\hline $\mathbf{C}$ & 108.214 & 22.753 & 4.756 & $0.000 * * *$ \\
\hline ECM & -0.432 & 0.091 & -4.754 & $0.000 * * *$ \\
\hline \multicolumn{5}{|c|}{$\mathrm{R}^{2} \quad=0.71$} \\
\hline
\end{tabular}

Source: Author's Computation using Eviews 11 (2021) 


\subsubsection{ARDL Results to Analyse the Effect of Energy Consumption on $\mathrm{CO} 2$ Emission in Nigeria.}

From the long-run analysis for the $\mathrm{CO} 2$ model, energy consumption exert positive effect on $\mathrm{CO} 2$ emissions at 1 percent level of significance as a percentage increase in energy consumption increases $\mathrm{CO} 2$ emissions by 16.3 percent. This conforms with a-priori expectation as energy consumption in Nigeria is mostly dominated by fossil fuels which have a huge hydrocarbon component and emits a great deal of $\mathrm{CO} 2$ into the atmosphere. Results corroborate findings by (Khalid et al., 2017; Lanouar, 2017; Aiyetan and Olomola, 2017; Yahaya et al., 2019).

Similarly, the squared value of GDP per capita affects $\mathrm{CO} 2$ emissions significantly at 5 percent. A percentage increase in the squared value of GDP per capita reduces $\mathrm{CO} 2$ emissions by 333.79 percent in the long run. This also conforms with a-priori expectation as posited by the EKC hypothesis, while corroborating findings by Aiyetan and Olomola, 2017; Egbetokun et al., 2019; Ali et al., 2021. Gross fixed capital formation and GDP per capita did not show significant effect on $\mathrm{CO} 2$ emissions.

For the short run analysis, energy consumption in the current period influences $\mathrm{CO} 2$ emissions positively and significantly at 1 percent. A percentage increase in energy consumption in this period increases $\mathrm{CO} 2$ emissions by 4.37 percent. Conversely, energy consumption in the two lagged period exhibits a negative influence on $\mathrm{CO} 2$ emissions as a percentage increase in energy consumption in this period, reduces $\mathrm{CO} 2$ emissions by 5.72 percent.
For gross fixed capital formation, results show a positive relationship with $\mathrm{CO} 2$ emissions in the current period. A percentage increase in gross fixed capital formation in the current period increases $\mathrm{CO} 2$ emissions by 0.37 percent, thus conforming with a-priori expectation. This is justified by the fact that energy drives a large percentage of plants and machineries used in production and since the energy consumed is largely non-renewable, CO2 emissions are likely to increase.

Similarly, an increase in GDP per capita increases CO2 emissions by 109.99 percent, implying a positive relationship between GDP per capita and CO2 emissions. This also corroborates findings by Aiyetan and Olomola, 2017; Egbetokun et al., 2019; Ali et al., 2021. This also conforms with a-priori expectation as a rise in GDP per capita is closely followed by an increase in emissions as posited by the EKC hypothesis. This is so because activities that increase GDP are driven by energy which increases environmental degradation.

The squared value of GDP per capita in the current period has a significantly negative relationship with $\mathrm{CO} 2$ emissions. A percentage increase in the squared value of GDP per capita reduces $\mathrm{CO} 2$ emissions by 240.7 percent. This is justified by the fact that as the economy develops, environmentally friendly measures are taken which includes energy efficiency, thereby reducing the level of environmental degradation. The speed of adjustment from short-run to long -run equilibrium given any shock in the model is about 43 percent. 
Table 8: ARDL results for model II

\begin{tabular}{|c|c|c|c|c|}
\hline \multicolumn{5}{|c|}{$\begin{array}{l}\text { Dependent Variable: LNEFP } \\
\text { Selected Model: } 4,4,4,3,3 \text {. }\end{array}$} \\
\hline Variable & Coefficient & Standard Error & T-Statistics & Probability \\
\hline \multicolumn{5}{|c|}{ LONG RUN ESTIMATES } \\
\hline LNENERGY & 1.229 & 0.852 & 1.440 & 0.177 \\
\hline LNGFC & -0.223 & 0.098 & -2.270 & $0.044 * *$ \\
\hline LNGDP & -15.866 & 3.768 & -4.210 & $0.001 * * *$ \\
\hline LNGDP $^{2}$ & 35.587 & 8.328 & 4.273 & $0.001 * * *$ \\
\hline \multicolumn{5}{|c|}{ SHORT RUN ESTIMATES } \\
\hline DLNEFP(-1) & -0.621 & 0.129 & -4.786 & $0.001 * * *$ \\
\hline DLNEFP(-2) & -0.630 & 0.142 & -4.443 & $0.001 * * *$ \\
\hline DLNEFP(-3) & -0.189 & 0.111 & -1.705 & 0.116 \\
\hline DLNENERGY & 0.013 & 0.201 & 0.063 & 0.950 \\
\hline $\begin{array}{l}\text { DLNENERGY(- } \\
\text { 1) }\end{array}$ & -0.200 & 0.264 & -0.762 & 0.462 \\
\hline $\begin{array}{l}\text { DLNENERGY(- } \\
\text { 2) }\end{array}$ & 0.153 & 0.202 & 0.755 & 0.466 \\
\hline $\begin{array}{l}\text { DLNENERGY(- } \\
\text { 3) }\end{array}$ & 0.710 & 0.211 & 3.368 & $0.006^{* * *}$ \\
\hline DLNGFCF & 0.012 & 0.025 & 2.239 & $0.046^{* *}$ \\
\hline DLNGFCF(-1) & 0.053 & 0.023 & 2.239 & $0.047 * *$ \\
\hline DLNGFCF(-2) & 0.022 & 0.025 & 0.862 & 0.407 \\
\hline DLNGFCF(-3) & -0.098 & 0.026 & -3.718 & $0.003 * * *$ \\
\hline DLNGDP & -17.615 & 5.591 & -3.150 & $0.009 * * *$ \\
\hline DLNGDP(-1) & 17.852 & 6.232 & 2.864 & $0.015^{* *}$ \\
\hline DLNGDP(-2) & 17.192 & 6.613 & 2.599 & $0.025 * *$ \\
\hline DLNGDP $^{2}$ & 36.969 & 12.159 & 3.040 & $0.011 * *$ \\
\hline DLNGDP $^{2}(-1)$ & -39.706 & 13.499 & -2.941 & $0.013 * *$ \\
\hline DLNGDP $^{2}(-2)$ & -37.711 & 14.431 & -2.613 & $0.024 * *$ \\
\hline ECM & -0.749 & 0.101 & -7.389 & $0.000 * * *$ \\
\hline $\begin{array}{ll}\mathrm{R}^{2} & =0.8 \\
\text { Adjusted } \mathrm{R}^{2 .} & =0 .\end{array}$ & & D.W. Statistics & 2.44 & \\
\hline
\end{tabular}

Source: Author's Computation using Eviews 11 (2021)

3.5.2. ARDL Results to Analyse the Effect of Energy Consumption on EFP in Nigeria.

From the ARDL estimates for the second model, long run results showed that gross fixed capital formation has a negative and significant effect on ecological footprint (EFP). This implies that a percentage increase in gross fixed capital formation brings about 0.23 percent decrease in EFP in the long run. Similarly, for the long run, GDP per capita exhibits a negative relationship with EFP at 1 percent. A percentage increase in GDP per capita reduces EFP by 15.86 percent, while a percentage increase in the squared value of GDP per capita increases EFP by 35.58 percent. This is justified by the fact that as the economy develops, production and consumption increase, thereby depleting the available ecological assets, such that it becomes difficult for the environment to absorb emitted waste emanating from improved technology.

For the short run estimates, one and two lagged values of EFP have significantly negative relationships with current EFP as a percentage increase in these variables reduce current EFP by 0.62 and 0.63 percent respectively. Energy consumption in the three lagged period also has a positive and significant effect on EFP, with a percentage increase in energy consumption in this period, increasing EFP by 0.71 percent. Gross fixed capital formation in the current and one lagged period also has a positive relationship with EFP. A percentage increase in gross fixed capital formation in these periods is seen to increase EFP by 0.01 and 0.05 percent respectively. Conversely, gross fixed capital formation in the three lagged period has a negative relationship with EFP as a percentage increase in this variable reduces EFP by 0.09 percent.

GDP per capita in the current period has a negative effect on EFP, while GDP per capita in the one and two lagged periods exert positive influence on EFP. A percentage increase in GDP per capita in the current period, reduces EFP by 17.61 percent, while a percentage increase in GDP per capita in the one and two lagged periods increase EFP by 17.85 and 17.19 percent respectively. This validate findings by (Charfeddine, 2017; Apergis and Ozturk, 2015).

The squared value of GDP per capita in the current period has a positive relationship with EFP, and a negative effect is observed for the one and two lagged values of this variable. A percentage increase in the squared value of GDP per capita in the current period is seen to increase EFP by 36.96 percent, while a percentage increase in the squared value of GDP per capita in the 
one and two lagged periods reduce EFP by 39.71 and 37.71 percent respectively.

The error correction term reported in the short run analysis is statistically significant, negative and less than one. This means that the speed of adjustment from short-run to long -run equilibrium given any shock in the model is about 75 percent.

\subsection{ARDL Post-Diagnostic Test}

3.6.1. Serial correlation, Heteroskedasticity, and Normal Distribution tests.

Table 9: Post-Diagnostic Test

\begin{tabular}{|c|c|c|}
\hline Test Statistic & $\begin{array}{c}\text { Model (I) } \\
\text { Probability } \\
\text { Value }\end{array}$ & $\begin{array}{c}\text { Model (II) } \\
\text { Probability } \\
\text { Value }\end{array}$ \\
\hline$\square$ Normality test & 0.514 & 0.156 \\
\hline$\square$ Serial correlation & 0.082 & 0.768 \\
\hline$\square$ Heteroskedasticity & 0.201 & 0.131 \\
\hline
\end{tabular}

Source: Author's Computation using Eviews 11 (2021)
The result shows absence of serial correlation and heteroskedasticity. There is also a normal distribution of the residuals.

\subsubsection{Plots of Cumulative Sum of Residuals (CU- SUM)}

CUSUM is a test of stability of a model. The standard error boundary is plotted around zero and any statistic outside the boundary is assumed to be an evidence of parameter instability.

The CUSUM test shows that the model is stable.

\subsubsection{Plot of Cumulative Sum of Squares of Recursi- ve Residuals (CUSUMSQ)}

The CUSUMSQ test is also a test of parameter stability.

Fig.1: Plot of CUSUM

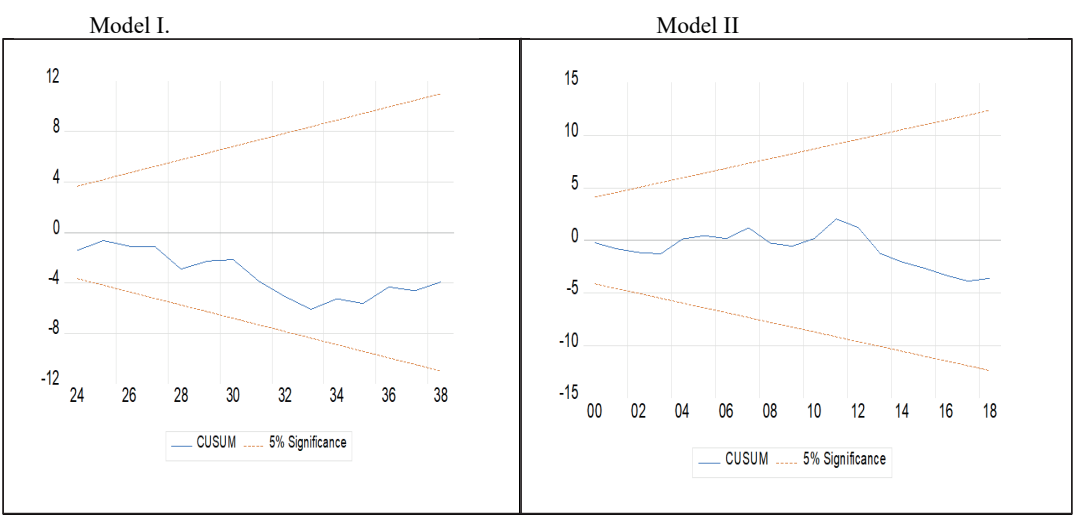

Source: Author's Computation using Eviews 11 (2021)

Fig 2: Plot of CUSUM of Squares

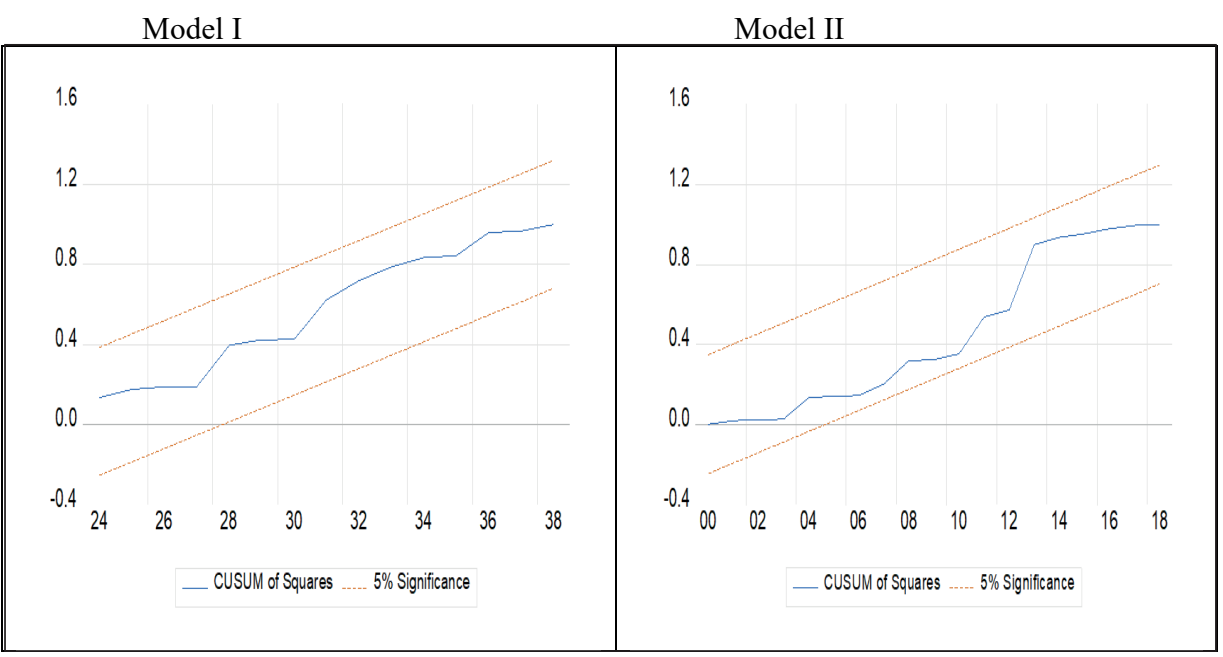

Source: Author's Computation using Eviews 11 (2021) 
Since the line lies within the confidence bounds, the conclusion is that the model is stable.

\subsection{Testing the validity of the Environmental Kuz- nets Hypothesis for Nigeria}

Given the condition of the EKC to be: If $\beta 1>0, \beta 2$ $<0$, an inverted $U$ relationship that validates the EKC exists. From the ARDL results for the $\mathrm{CO} 2$ model, the short run and long run results validates the existence of the EKC for Nigeria. Results indicate $\beta 1>0$ (i.e. 135.620 ) and $\beta 2<0$ (i.e. -333.792 ) in the long run and $\beta 1>0$ (i.e. 109.986) and $\beta 2<0$ (i.e. -240.788) in the short run which validates proof of the EKC. This corroborates findings by Aiyetan and Olomola, 2017; Egbetokun et al., 2019; Ali et al., 2021..

However, for the EFP model, both short run and long run analysis refutes the existence of the EKC for Nigeria. Results revealed that in the long run, $\beta 1<0$ (i.e. -15.866) and $\beta 2>0$ (i.e. 35.587), and for the short run, $\beta 1<0$ (i.e. -17.852) and $\beta 2>0$ (i.e. 36.969), which refutes the existence of the EKC hypothesis for Nigeria. The EKC hypothesis is therefore valid for Nigeria only for the $\mathrm{CO} 2$ model. It is worthy to note that the result for EFP is inconsistent with that obtained for CO2. Therefore, the effect of per capita GDP on the environment is subject to the environmental indicator used by the empirical analysis.

The turning point of income level at which environmental degradation starts to decline is calculated in the long run and given as:

$$
Y^{*}=\frac{-\beta_{1}}{2 \beta_{2}}
$$

From the ARDL results, $\beta 1=135.620$ and $\beta 2=-333.792$

Therefore, $\mathrm{Y}^{*}=-135.620 / 2(-333.792)$

$=0.20315$

The variable $\mathrm{Y}$ is measured in logarithm form, therefore, $\exp \left(\mathrm{Y}^{*}\right)$ will yield the monetary value representing the peak of the EKC.

$\exp (0.20315)=1.225$

The study therefore observed that the income level at which environmental degradation starts to decline for Nigeria otherwise known as the turning point is $\$ 1.225$.

\section{CONCLUSION AND POLICY RECOM- MENDATIONS}

While examining the nexus between energy consumption and environmental degradation in Nigeria within the framework of the EKC hypothesis, the study employed yearly data from 1981 to 2019 . Two environmental indicators were employed in the comparative analysis and the estimation of the EKC hypothesis for Nigeria. For effective estimation, each environmental indicator was modelled differently using the ARDL method after establishing cointegration with the Bound test.

The study revealed that in the short and long run, energy consumption has positive effects on $\mathrm{CO} 2$ emissions in Nigeria. However, for EFP, only energy consumption in the three lagged period positively influenced EFP in the short run. In the long run, estimates reveal that energy consumption does not significantly influence on EFP. Empirical evidence also shows that the EKC hypothesis is valid for Nigeria only when environmental degradation is measured with $\mathrm{CO} 2$ emissions.

An inverted U-shaped environmental degradation-economic development relationship was established in the study which adhered strictly to the EKC hypothesized inverted U-shape. It is worthy to note that the result for EFP is inconsistent with that obtained for CO2. Therefore, the shape of the EKC curve is subject to the environmental indicator used by empirical analysis.

The study recommends that as the country's demand for energy increases, attention should be given to environmental impacts of such process. A viable proportion of alternative energy should be included in the country's energy mix to address both the energy needs as well as the environmental concerns due to $\mathrm{CO} 2$ emissions which causes environmental degradation. This will assist in reducing environmental pollution and at the same time sustain long run economic growth. Similarly, the pollution behavior of firms and individuals consuming energy should be regulated by setting an emission standard in the country and defaulters be penalized strictly.

\section{REFERENCES}

ADENIRAN, O. (2009). Does energy consumption cause economic growth? An empirical evidence from Nigeria. Thesis (Masters). University of Dundee.

AIYETAN, I. \& OLOMOLA, P. (2017). Environmental degradation, energy consumption, population growth and economic growth: Does Environmental Kuznets curve matter for Nigeria? Economic and Policy Review, 16 (2), 24-36.

AKPAN, U.F., \& CHUKU, A. (2011). Economic Growth and Environmental Degradation in Nigeria: Beyond the Environmental Kuznets Curve. Retrieved from https://ideas.repec.org/p/pra/mpra$\mathrm{pa} / 31241 . \mathrm{html}$.

ALEGE, P. \& OGUNDIPE, A. (2013). Environmental quality and 
economic growth in Nigeria: A fractional cointegration analysis. International Journal of Development and Sustainability, 2(2) . Retrieved from www.isdsnet.com/ijds.

ALI, A., USMAN, M., USMAN, O., AND SARKODIE, S. (2021). Modeling the Effects of Agricultural Innovation and Biocapacity on Carbon Dioxide Emissions in an Agrarian-Based Economy: Evidence from the Dynamic ARDL Simulations. Frontiers in Energy Research, 8, 381. Retrieved from https://www.frontiersin.org/article $/ 10.3389 /$ fenrg. 2020.592061

ALOLA, A., K. YALÇINER,K.,ALOLA,U. ,AKADIRI,S.(2019). The role of renewable energy, immigration and real income in environmental sustainability target. Evidence from Europe largest states. Sci. Total Environ, 1-15

APERGIS,L., \& OZTURK, (2015). Testing Environmental Kuznets Hypothesis in Asian countries. Ecological Indicators, 52, 16-22.

CHARFEDDINE, L. (2017). The impact of energy consumption and economic development on Ecological Footprint and $\mathrm{CO}_{2}$ emissions: Evidence from a Markov Switching Equilibrium Correction Model. Energy Economics, 65, 355-374

EGBETOKUN,S., OSABUOHIEN, E. AKINBOBOLA, T.,ONANUGA,O.,GERSHON, O., OKAFOR, V.(2019). Environmental pollution, economic growth and institutional quality: Exploring the nexus in Nigeria, AGDI Working Paper, No. WP/19/059, African Governance and Development Institute (AGDI), Yaoundé

EZATOLLOH, A., NAZARI, M., AND NASRINDOOST, M. (2010). Energy Consumption and Economic Growth in the Iranian Economy: Testing the Causality Relationship. Middle-East Journal of Scientific Research, 5(5), 374- 381.

GEORGE, E.H. \& NICKOLOAS, G.T. (2011). The Effect of Energy Consumption on Economic Growth on countries Economic Efficiency: A Conditional Non-Parametric Approach: MPRA Paper (28692).

GLOBAL FOOTPRINT NETWORK. (2018). Available at https:// www.footprintnetwork.org/2019/01/05/2018-highlights/ Accessed on the $15^{\text {th }}$ May 202.

INTERNATIONAL ENERGY OUTLOOK (2019). Available at https://www.eia.gov/outlooks/ieo/.

KHALID, Z., \& MITWALI ABD-EL, M. (2017). Energy consumption, carbon dioxide emissions and economic development: Evaluating alternative and plausible environmental hypothesis for sustainable growth. Renewable and Sustainable Energy Review $74,1119-1130$.

MRABET, Z., ALSAMARA, M.\& JARALLAH, S. (2017). The impact of economic development on environmental degradation in Qatar. Environmental and Ecological Statistics, 24(1), 7-38.

NATIONAL BUREAU OF STATISTICS (2021). Available at https://www.nigerianstat.gov.ng. Accessed on $6^{\text {th }}$ September, 2021.

NATHANIEL, S.P. (2020), Modelling urbanization, trade flow, economic growth and energy consumption with regards to the environment in Nigeria. Geo Journal 85,1499-1513.

ODHIAMBO, N.M. (2009). Energy consumption and economic growth nexus in Tanzania: an ARDL bounds testing approach. En- ergy Policy, 37, 617-622.

ODULARO, G.O. \& OKONKWO, C., (2009). Does Energy Consumption Contribute to Economic Performance? Empirical Evidence from Nigeria. Journal of Economics and International Finance 1(2), 44-58.

OMISAKIN, A.O. (2009). Economic Growth \& Environmental Quality in Nigeria: Does Environmental Kuznets Curve hypothesis hold? Environmental Research Journal, 3(1), 14-18.

OMOTOR, D. (2008). Causality between energy consumption and economic growth in Nigeria. Pakistan Journal of Social Sciences, 5(8), 827-835.

SABOORI, B., AND SULAIMAN, J.(2013). Environmental degradation, economic growth and energy consumption: Evidence of the environmental Kuznets curve in Malaysia. Energy Policy, 60C, 892-905.

TSANI, S.Z. 2010. Energy consumption and economic growth: A causality analysis for Greece. Energy Economics 32, 582-590.

WORLD RESOURCES INSTITUTE (2021). 4 Charts explaining greenhouse gas emissions by countries and sectors. Available at https://www.wri.org. Accessed on $6^{\text {th }}$ September, 2021.

YAHAYA, N.S.., RAZANI, B, MOHD, J., JIMOH O. (2019). Energy Consumption and Environmental Pollution in Nigeria. Academic Journal of Economic Studies, Faculty of Finance, Banking and Accountancy Bucharest, "Dimitrie Cantemir" Christian University Bucharest, 5(1), 24-30. 